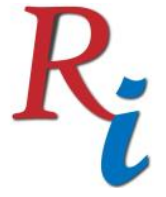

Asia Proceedings of Social Sciences

(APSS)

www.readersinsight.net/APSS

\title{
Connenting Retail Marketing Mix and Trust in Store with Purchase Behavior in Developing Country: A Mediated Role of Purchase Intention.
}

\author{
Numair Ahmed Sulehri* \\ COMSATS University Islamabad \\ Pakistan
}

\section{Mansoor Ahmed}

COMSATS University Islamabad

Pakistan

*Corrosponding author's Email:sulehri39@gmail.com 


\section{Research High Iight s}

In the retail industry of Pakistan the marketing practices are not settled. Reatilers practices to use marketing for strentening their position in the competetion is still clustered around the target areas. However, the current study had explored the link of marketing efforts to the purchase behavior. More importantly, this study had explored the link between purchase intention and purchase behavior.

This study had two main hypothesis. First, exploring the mediated role of purchase intention between retail marketing mix and purchase behavior. Second, exploring the mediated link of purchase intention between trust in store and purchase behavior. Results had indicated that partial mediation exist between the two main hypothesis. Reatil marketing mix in developing contry was partially intervened with purchase intention to purchase behavior. On other hand, Trust in store was found to strenthen the purchase behavior in Pakistan with partial intervention of purchase behavior.

\section{Graphic a I A bst r a c t}

Following figure summrises the result of current study.

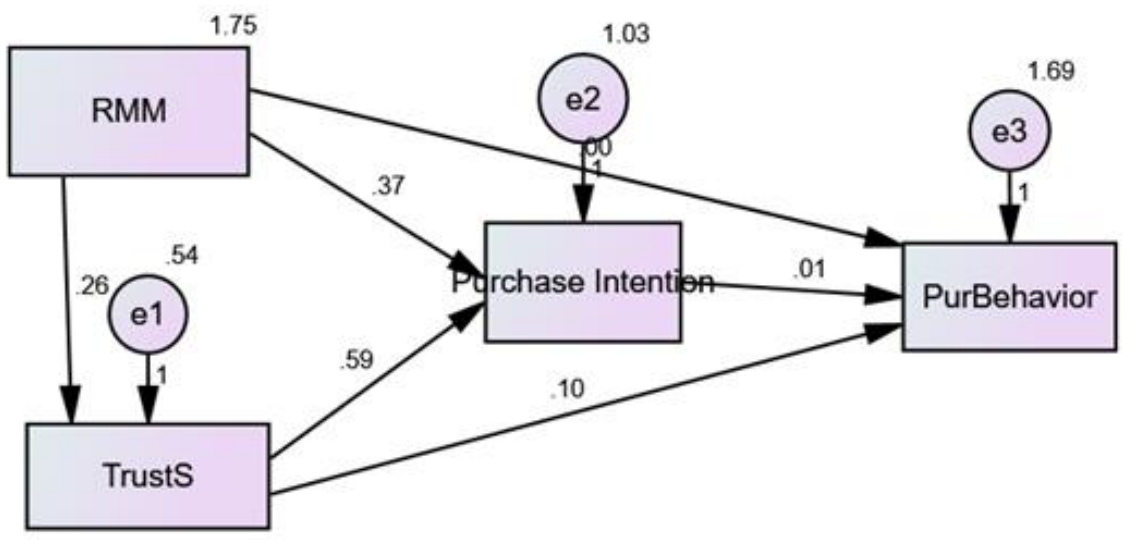




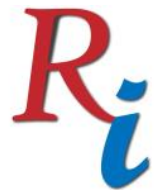

Asia Proceedings of Social Sciences

(APSS)

www.readersinsight.net/APSS

\section{Research Objectives}

Purpose: of the study was to evaluate the marketing practice in retail sector of a developing country and the trust effect on purchase desion making.

Objectives: this study had two main objectives. Foremost was the investigation the impact of marketing mix efforts of retail towards purchase process. Secondly; the investigation of trust in store towards purchase behavior

Significance: this study had given insight for intention behavior gap (Sheeran and Webb, 2016). It had also added into rarely explored field of retail in developingg country.

\section{Methodology}

Quatitative reserch methedology was adopted with noncontrived sample technique. Structural equational modeling method was used to analyse thae data and interpetation of the results.

Sample was collected from eight difrent retail stores in three cities at diffrent tome to make the sample as more representative. The data was collected online with the help of smart phones (Lefever et al., 2007a). This technique had enabled to collect data from multiple sites simultaneosly and with precision. The data was put in an excel sheet and it was transfered to SPSS for making structural model on AMOS and eveluation with diffrent criteria (Amos et al., n.d.). The questionier was made in two languages, english and local language, so that the respondent was been able to understand and respond accurately (Chidlow et al., 2014). The data was cillected between a period of two months and ten days.

The aims and objectives of the research were been explained to each respondent before the filling of the qustioneir. Data annonamity and exclusivitty of the respondent openion for the current reserch was also told to each respondent.

The data was collected at the point of sale, when customers were waiting on the check out counters for their turn. This pont was more appropriate because the customers had the fresh memories of the purchase perceptions and they were been able to respond better (Lefever et al., 2007b). 


\section{Results}

\begin{tabular}{|l|l|l|l|l|}
\hline Table 1. The Mediating roles \\
\hline Description of Paths & $\begin{array}{l}\text { Direct } \\
\text { Effect }\end{array}$ & $\begin{array}{l}\text { Direct With } \\
\text { Mediator }\end{array}$ & $\begin{array}{l}\text { Indirect } \\
\text { Effect }\end{array}$ & Mediation \\
\hline $\begin{array}{l}\text { Retail Marketing Mix } \rightarrow \text { Purchase Intention } \\
\rightarrow \text { Purchase Behavior }\end{array}$ & $0.476^{* *}$ & $0.032^{*}$ & $0.413^{* *}$ & Partial \\
\hline $\begin{array}{l}\text { Trust store } \rightarrow \text { Purchase Intention } \rightarrow \text { Purchase } \\
\text { Behavior }\end{array}$ & $0.373 * *$ & $0.007^{*}$ & $0.531^{* *}$ & Partial \\
\hline$* * \mathrm{p}<0.01, * \mathrm{p}<0.05$ & & & & \\
\hline
\end{tabular}

The above table mediated effect of purchase intention among retail marketing mix in store and purchase behavior for urban consumers was displayed. The straight effect of retail marketing mix store with purchase behavior was found as significant with an size of 0.476. After the introduction of purchase intention as the mediator, the significance level is decreased and the effect size is also changed (0.032 at $\mathrm{p}<.05$ and $\left.0.413^{* *}\right)$. This change had indicateed partial intervention of purchase intention for retail marketing mix and purchase behavior of the customers (Frazier et al., 2004).

Moreover, for the explanation of second objective, stating the mediated connection of purchase intention for trust in store and purchase behavior in urban consumers from the above table. The direct effect of trust in store with purchase behavior was found as significant with an effect of 0.373 from above table. The effect of changed when purchase intention was introduced as mediator. The the significance level was decreased and the effect size also changed after the mediator $\left(0.07\right.$ at $\mathrm{p}<.05$ and $\left.0.531^{* *}\right)$. This change indicates partial mediation of purchase intention between retail trust in store and purchase behavior of the retail customers (Frazier et al., 2004).

\section{Findings}

The ratil industry in pakistan is in transition and diffrent retailers are practicing diffrennt marketing techniques. According to the results of this study, trust plays a very significant role in the purchase decision making of the urban retail customers. The customer choice of retailer remains constant for a considerable period of time, until another retailer influences the trust of the customer through its marketing techniques. The customers in Pakistan are exploring diffrentt organised retailes. That menas visiting them for grocery shopping (Aman and Hopkinson, 2010). Most of the customer want to visit the retail centre offering better retail marketing mix an an approchable distance (Sulehri and Ahmed, 2017). 


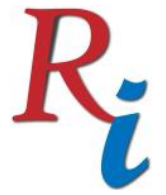

\section{Asia Proceedings of Social Sciences \\ (APSS) \\ www.readersinsight.net/APSS}

With the addittion of more product range, retail and non retail tenents organised retailers had started created an image to their customers. But the marketing techniques are limited to the retail sopace and are targeting geographically narrow segment of one city only.

In the comming years, the retail land scape would change and new national and international players will enter in the local retaile industry.

\section{References}

Aman, A., Hopkinson, G., 2010. The changing structure of distribution channels in Pakistan. Int. J. Retail Distrib. Manag. 38, 341-359.

Chidlow, A., Plakoyiannaki, E., Welch, C., 2014. Translation in cross-language international business research research. J. Int. Bus. Stud. 45, 562-582.

Frazier, P.A., Tix, A.P., Barron, K.E., 2004. Testing Moderator and Mediator Effects in Counseling Psychology 51, 115-134.

Lefever, S., Dal, M., Matthíasdóttir, Á., 2007a. Online data collection in academic research: advantages and limitations. Br. J. Educ. Technol. 38, 574-582.

Lefever, S., Dal, M., Matthíasdóttir, Á., 2007b. Online data collection in academic research: advantages and limitations. Br. J. Educ. Technol. 38, 574-582.

Sheeran, P., Webb, T.L., 2016. The Intention - Behavior Gap. Soc. Personal. Psychol. Compass 10, 503-518.

Sulehri, N.A., Ahmed, M., 2017. Theory of reasoned action and retail agglomerations buying behavior for urban consumers. Bus. Manag. Rev. Conf. Proc. Acad. Bus. Retail Manag. 9. 